\title{
NUORET JA ELÄVÄ TOIMIJUUDEN TUNTO ELÄMÄNKULUN KÄÄNNEKOHDISSA
}

Anna Juntunen: TT, Helsingin yliopisto

anna.juntunen@evl.ji

Janus vol. 28 (1) 2020, 20-41

Tiivistelmä

\section{(山) in II S}

VERTAISARVIOITU
KOLLEGIAL GRANSKAD
PEERR REVIEWED
www. tsv.filtunnus

Artikkelissa tutkin 14-20-vuotiaiden nuorten elämänkulun käännekohtia toimijuuden tunnon näkökulmasta. Toimijuuden tunnolla viitataan nuoren kokemukseen mahdollisuudesta tehdä valintoja ja toteuttaa niitä (Gordon 2005). Aineistona ovat nuorten haastattelut, heidän elämänspiraalinsa ja valokuvat heille tärkeistä asioista tai ihmisistä. Artikkelin tulokset rakentuvat kolmen pääteeman ympärille: 1. kokemus sosiaalisesta tuesta, vastuusta ja yhteenkuuluvuudesta elämänkulun käännekohdissa, 2. autonomian kokemukset elämänkulun käännekohdissa ja 3. minäpystyvyys elämänkulun käännekohdissa. Tulokset osoittavat nuorten toimijuuden tunnon vaihtelevan elämänkulun sosiaalisissa, institutionaalisissa, sattumanvaraisissa ja voimaantumisen käännekohdissa. Nuoren toimijuuden tuntoa ei voi tarkastella vain vahvana tai heikkona, sillä usein nuoressa on monia erilaisia toimijuuksia tilanteesta riippuen. Käännekohdat voivat muokata nuoren toimijuuden tuntoa ja toisaalta toimijuuden tunto voi vaikuttaa nuoren suhtautumiseen elämään elämänkulun moninaisissa käännekohdissa.

\section{NUORUUDEN SIIRTYMÄT JA TOIMIJUUDEN IHANNE}

Tässä artikkelissa tutkin nuorten elämänkulkujen käännekohtia toimijuuden tunnon käsitteen avulla.Tuon esille haastateltavien kokemuksia toimijuuden tunnosta niissä hetkissä ja tapahtumissa, jotka nuoret mieltävät elämänsä käännekohdiksi. Toimijuuden tunto on yksilön oma kokemus toimijuutta mahdollistavista ja rajoittavista asioista (Gordon 2005; Paju 2013). Ymmärrän toimijuuden tunnon muotoutuvan yksilön ja erilaisten rakenteellisten, kulttuuristen ja sosiaalisten kontekstien vuorovaikutuksessa. Tutkimukseni edustaa monitieteistä elämänkulkututkimuksen perinnettä, jossa ihmisen elämää, kokemuksia ja toimijuutta tar- kastellaan ajallisuuden näkökulmasta (Elder \& Giele 2009).

Hallituksen lapsi- ja nuorisopoliittiset kehittämisohjelmat pohjautuvat ajatukseen elämänkaaripolitiikasta, jossa ihmisen elämä nähdään kaarena lapsuudesta nuoruuteen ja nuoruudesta aikuisuuteen. Suomalaista nuorisopolitiikkaa on kritisoitu sen elämänkaaripoliittisesta painotuksesta, jossa nuoren elämänkulkua on tarkasteltu siirtymien ja niihin liittyvien palvelujen näkökulmista. (Suurpää 2009, 12-13.) Tutkimuksellinen ja julkinen keskustelu nuorten elämänkulkuihin liittyvästä toimijuudesta kiinnittyy usein erilaisiin nivelvaiheisiin ja siirtymiin. Nivelvaiheilla tarkoitetaan niitä hetkiä, kun nuoren oletetaan ottavan seuraavan as- 
keleen koulutuksellisella polulla, vaikkapa peruskoulun jälkeen (Vehviläinen $2006,31)$. Siirtymät elämänkulussa voivat tarkoittaa esimerkiksi koulutuksellisia, ammatillisia tai itsenäistymiseen liittyviä askelia (Ecclestone ym. 2010). Nuorten elämänkulkuihin liittyvän toimijuuden tutkimisessa ovat korostuneet institutionaaliset siirtymät ja erityisesti poikkeamat institutionaalisilta poluilta (esim. Aaltonen \& Lappalainen 2013; Tolonen 2005). Olettamusta erilaisten ikäsidonnaisten elämänvaiheiden läpikäymisestä ja siirtymistä ei voida pitää enää relevanttina, sillä nuoret rakentavat toimijuudellaan omanlaisiaan, yksilöllisiä elämänkulkuja (Ecclestone ym. 2010).

Nuorisotutkija Leena suurpää nostaa esille elämänkaaripolitiikan uhkakuvia, kuten ajatuksen nuoren lineaarisesti ja normien mukaisesti etenevästä elämänkulusta. Elämänkaaripoliittinen näkökulma nuoruuteen ei huomioi riittävästi nuorten yksilöllisiä elämänkulkuja. Suurpää esittää, että elämänkaaripolitiikan sijaan puhuttaisiin elämänkulkupolitiikasta, jossa nuoren elämä ei näyttäydy vain ennalta arvattavana siirtymien ja tapahtumien ketjuna, vaan yksilöllisenä elämänpolkuna. (Suurpää 2009, 12-13.) Elämänkulun tarkasteleminen siirtymien näkökulmasta voi niputtaa nuoret yhdeksi ryhmäksi. Siirtymïa arvioidaan usein edellisten sukupolvien näkökulmasta, joiden perintöön nuorten odotetaan liittyvän. (Wyn \& Woodman 2006, 511.)

Nuorten toimijuuteen kohdistuu moninaisia vaatimuksia ja ihanteita, jot$\mathrm{ka}$ voivat olla erilaisten palvelujärjestelmien ylläpitämiä rakenteellisia ja kulttuurisia odotuksia. Usein nuoren toimijuuden synonyymina käytetään aktiivisuuden ja osallisuuden käsitteitä (Kiilakoski 2012, 222). Keskustelu nuorten toimijuudesta painottaa toimijuuden rajallisuutta ja reunaehtoja. Toimijuus tai sen puute liittyvät kysymykseen vallasta ja esitetäänkin, että toimijuuden edellytyksenä on ihmisen kokemus mahdollisuudesta valita, tehdä toisin tai löytää merkityksiä elämänkulun tapahtumista (Ronkainen 2008).

\section{ELÄMÄNKULKU JA KÄÄNTEENTEKEVÄT KÄÄNNEKOHDAT}

Elämänkululla (life course) tarkoitetaan yksilön omaa kokemuksellista kertomusta hänen elämänsä vaiheista, johon vaikuttavat muun muassa ikä, sukupuoli ja merkitykselliset tapahtumat sekä rakenteelliset tekijät (Settersten 2003). Yksilön toimijuutta, elämäntilannetta tai kokemuksia ei voida ymmärtää, mikäli tarkastellaan vain ihmisen nykyistä elämänvaihetta (Elder \& Giele 2009). Elämänkulkua ei tule nähdä elämänkaaren käsitteen synonyymina. Elämänkaaren käsitteeseen liittyy ajatus ihmisen normatiivisesti ja yksiselitteisesti etenevästä elämästä. Elämänkulun käsite huomioi yksilölliset ja moninaiset elämänpolut, jotka sisältävät erilaisia reittejä ja aikataulutuksia. (Nikander 1999, 29.)

Nuoren elämänkulku nivoutuu erilaisiin sosiaalisiin konteksteihin, joissa hän elää. Ihmissuhteet, kulttuuriset ilmiöt, yhteiskunnalliset rakenteet ja historialliset tekijät vaikuttavat elämänkulun rakentumiseen (Settersten 2003, 2). Yksilölle on luontevaa tulkita elämäntapahtumia ja niiden merkityksiä suhteessa toisiin ihmisiin (Elder 1998). 
Nuorella itsellään on myös mahdollisuuksia muovata elämäänsä valintojensa ja arvojensa pohjalta (Piispa \& Salasuo 2014, 24-25). Nuoruutta pidetään aikana, jolloin oman elämänkulun merkitykset alkavat nivoutua identiteetin palasiksi (Habermas 2010). Identiteetillä ei tarkoiteta pelkästään käsitystä itsestä, vaan myös muista ihmisistä ja ryhmäjäsenyyksistä. Identiteetti ei ole pysyvä ominaisuus, vaan pikemminkin muuttuva prosessi. Identiteetin käsite kietoutuu ajallisuuteen, sillä läpi elämänkulun ihminen joutuu pohtimaan kysymyksiä siitä, millainen hän oli, on tällä hetkellä ja millaiseksi hän on tulossa. (Hall 2002, 223.)

Elämänkulun käännekohdilla (turning points) tarkoitetaan tapahtumia, joiden seuraukset voivat merkitä pitkäaikaisia muutoksia ja murroksia yksilön elämässä. Käännekohdat muuttavat ihmisen elämänkulkua ja ne syntyvät omien valintojen, ratkaisujen tai yllättävien tapahtumien myötä. Ihmisen subjektiivinen kokemus elämäntapahtuman merkityksestä ja sen vaikutuksesta määrittää sen, mitkä hetket, tapahtumat ja kohtaamiset nousevat hänen elämänsä käännekohdiksi. Käännekohtien merkitykset voivat avautua ihmiselle vasta myöhemmässä elämänkulussa, kun hän kykenee arvioimaan käännekohtien pitkäaikaisia vaikutuksia. (Rutter 1996.)

Nuorten elämänkulkujen käännekohdat liittyvät esimerkiksi ihmissuhteisiin, itsenäistymiseen ja yllättäviin elämäntapahtumiin, kuten sairastumiseen tai läheisen menettämiseen (Thomson ym. 2002). Käännekohta voi tarkoittaa esimerkiksi kriittistä hetkeä, jolloin nuori oivaltaa elämänsä suuntaviivoja
(Piispa 2013, 26-27). Aiemmassa tutkimuksessa nuorten elämänkulkuja on analysoitu käännekohtien sekä kriittisten ja kohtalokkaiden hetkien näkökulmasta. Kriittiset hetket voidaan nähdä elämänkulun käännekohtina, jotka vaikuttavat nuoren identiteettiin ja elämänkulkuun. Kriittisiä hetkiä tutkimalla pyritään tavoittamaan nuoren elämän käännekohtia,jotka eivät välttämättä liity institutionaalisiin siirtymiin. (Henderson ym. 2007; Shildrick \& MacDonald 2008.) Käännekohdalla ei tarkoiteta samaa kuin siirtymällä, vaikkakin siirtymä voi yksilön kokemuksessa merkitä käännekohtaa. Jotta siirtymästä tulee käännekohta, tulee sen jollain tapaa muuttaa ihmisen suhtautumista itseen, kanssaihmisiin ja ympäröivään maailmaan. (Rutter 1996.)

\section{TOIMIJUUDEN TUNTO JA \\ ELÄMÄNKULUN KÄÄNNEKOHDAT}

Nuorten toimijuutta tutkineen Tuula Gordonin mukaan toimijuuden punaisena lankana voidaan pitää ihmisen tunnetta ja kokemusta siitä, että hänellä on mahdollisuus tehdä valintoja ja päätöksiä omaa elämäänsä koskien. Ihmisen kokemukseen mahdollisuudesta tehdä valintoja vaikuttavat moninaiset sosiaaliset, kulttuuriset, yhteiskunnalliset ja materiaaliset tekijät. Gordon nimittää ihmisen käsitystä hänen omista mahdollisuuksistaan päätöksentekoon ja sen toteuttamiseen toimijuuden tunnoksi (sense of agency). (Gordon 2005.) Psykologit Mark Cummings ja Alice Schermerhorn erottavat toisistaan toimijuuden toteuttamisen ja toimijuuden tunnon käsitteet. Toimijuuden toteuttaminen ymmärretään nuoren toiminnaksi ja tekemiseksi, kun 
taas toimijuuden tunto on nuoren kokemusta hänen omista mahdollisuuksistaan vaikuttaa ja valita. (Cummings \& Schermerhorn 2002, 94-95.)

Käännekohta ja toimijuuden tunto ovat molemmat ihmisen mielensisäisiä prosesseja, joissa korostuvat yksilön kyky kohdata elämänmuutoksia ja tunne siitä, että hän voi vaikuttaa omaan elämäänsä (Gordon 1995; Rutter 1996). Toimijuuden tunnon puute kyvyttömyytenä vaikuttaa käännekohdissa voi johtaa heikkenevään hyvinvointiin tai tyytymättömyyteen (Holland \& Thomson 2009). Aiemman tutkimuksen mukaan ihmiselle on luontevaa mieltää elämänkulun käännekohdiksi ne hetket, jolloin hän kokee voivansa omilla valinnoillaan vaikuttaa elämäänsä (Clausen 1995). Näin ollen käännekohdat kulkevat käsikädessä toimijuuden tunnon kanssa, sillä käännekohtia voidaan määritellä valinnanmahdollisuuden näkökulmasta.

Kulttuuriset normit, vuorovaikutustilanteet ja sosiaaliset kategoriat tarjoavat erilaisia toimijuuksia, joissa yksilön kokemus valinnanmahdollisuuksista vaihtelee (Ronkainen 2006). Feministisissä toimijuusteorioissa painotetaan erilaisten sosiaalisten kategorioiden, kuten sukupuolen, iän ja seksuaalisuuden merkitystä toimijuuden muotoutumisessa. Esimerkiksi sukupuoli vaikuttaa toimijuuden resursseihin ja siihen kohdistuviin odotuksiin. Sosiaaliset kategoriat ylläpitävät erilaisia rakenteellisia järjestyksiä, joihin ihmisiä luokitellaan muun muassa iän ja sukupuolen perusteella. (Ojala ym. 2009; Ojala 2010, 13.) Toimijuuden mahdollisuudet näkyvät esimerkiksi miesten ja naisten työurissa. Sukupuolittuneet normit ja ihanteet voivat johtaa pakotettuun ammatinvalintaan, vaikka ihmisen omat mielenkiinnon kohteet suuntautuisivat toisaalle. (Vaattovaara 2015.)

Aiemmassa tutkimuksessa on painottunut erityisesti haastavassa elämäntilanteessa elävien nuorten käännekohtien ja toimijuuden kokemuksen tarkasteleminen. Tutkimuksen kohteena ovat olleet esimerkiksi syrjäytyneet ja sairastuneet nuoret (esim. Ansell ym. 2011). Hass ja kumppanit ovat tutkimuksessaan selvittäneet huostaanotettujen nuorten elämänkulun käännekohtia, jotka ovat vieneet heitä elämässä eteenpäin. Tutkimuksesta ilmenee, että nuoren tunne mahdollisuudesta tehdä päätöksiä sekä kokemus sosiaalisesta ja aineellisesta tuesta ovat auttaneet nuoria selviytymään elämänkulun käännekohdissa. (Hass ym. 2014.) Elämänkulun käännekohdissa, kuten vanhempien erotessa tai parisuhteen kariutuessa, nuori voi kokea valinnanmahdottomuutta. Toisaalta elämänkulun käännekohdat voivat vahvistaa nuoren tunnetta itsestään toimijana ja kannustaa esimerkiksi itsenäistymisprosessissa. (Thomson ym. 2002.)

Toimijuuden tunnon ja elämänkulun käännekohtien suhde näyttäytyy aiemman tutkimuksen valossa vastavuoroisena. Käännekohdat muovaavat ihmisen käsitystä hänen omista mahdollisuuksistaan valita ja vaikuttaa. Joissakin elämänkulun käännekohdissa, kuten läheisen sairastuessa, nuoren toimijuuden tunto voi olla heikkoa (Hamilton \& Adamson 2013). Toisaalta toimijuuden tunto muovaa ihmisen suhtautumista elämänkulun moninaisiin käännekohtiin. Tällöin toimijuuden tunto ja luottamus itseen voivat auttaa nuorta sel- 
viytymään haastavassa elämäntilanteessa (Thomson ym. 2002).

\section{TUTKIMUSTEHTÄVÄ JA AINEISTO}

Artikkelin tutkimustehtävänä on selvittää, millaiset elämänkulun tapahtumat, hetket ja kohtaamiset nousevat haastateltujen nuorten kerronnassa käännekohdiksi ja miten nuorten toimijuus rakentuu näissä käännekohdissa. Tutkimusaineistona toimivat nuorten kanssa toteutetut haastattelut, valokuvat ja elämänspiraalit. Elämänspiraali on spiraalin muotoinen elämänkulkua kuvaava jana, johon nuoret merkitsivät elämänkulkujensa tärkeimpiä tapahtumia aina syntymästä haastatteluhetkeen saakka. Tämän artikkelin tulosluvuissa on esimerkkejä nuorten tekemistä spiraaleista (kuviot 1,2, 3 ja 4). Päädyin tutkimuksessani käyttämään spiraali-muotoa elämänkulun kuvaajana, sillä en halunnut typistää nuoren elämää tasaiseen janaan. Spiraalin laajenevat kerrokset kuvastavat nuoren elämänkulkua, jossa nykyisyyttä ja tulevaisuutta rakennetaan menneisyyden päälle. Spiraalia voidaan kuvata päättymättömäksi kehäksi, jossa elämänkulun tapahtumien tulkinta ei lopu koskaan. (Juntunen 2019.) Spiraaleissa korostuvat nuorten yksilölliset elämänkulun ajoitukset, jotka haastavat ajatusta elämänkaaripoliittisesta käsikirjoituksesta.

Nuoret tekivät spiraalit haastattelun aluksi ja he saivat kertoa niistä vapaasti. Tarvittaessa esitin nuorille lisäkysymyksiä heidän kerrontaansa liittyen. Lisäksi nuoret kertoivat valitsemistaan valokuvista. Olin pyytänyt nuoria tuomaan mukanaan kolme valokuvaa heille tärkeistä asioista tai ihmisistä. Valokuvissa kuvattiin moninaisia teemoja, kuten tärkeitä hetkiä, ystävïä, harrastuksia, perheenjäseniä, vapaa-aikaa, lemmikkejä ja oleskelupaikkoja. Suurin osa nuorten kuvista oli otettu älypuhelimilla. Nuoret kertoivat tuomistaan valokuvista vapaasti. Haastattelutilanteissa käytin tarvittaessa puolistrukturoitua haastattelurunkoa, jonka kysymykset liittyivät nuoren elämään, kuten arkeen, harrastuksiin, yhteisöihin, hyvinvointiin, arvoihin ja unelmiin.

Elämänspiraalit ja valokuvat toimivat nuorten kerronnan tukena sekä auttavat heitä jäsentämään heidän elämänkulkujaan. Kertomalla tuottamastaan aineistosta nuoret luovat elämästään tarinoita ja antavat elämäntapahtumilleen merkityksiä (McAdams 2011, 590; Mishler 1986).Valokuvien ja spiraaleiden kautta liityn narratiiviseen tutkimusperinteeseen. Ymmärrän tutkimustiedon rakentuvan nuorten kertomusten kautta. Tässä artikkelissa narratiivilla tarkoitetaan nuorten kertomuksia heidän elämästään. Nuorten kertomukset eivät edusta yhteistä tai yleistettävää totuutta, vaan ne ovat yksilöiden omia tulkintoja ja subjektiivisia kokemuksia (Burkitt 1999, 46). Spiraalit ja valokuvat täydentävät toisiaan tutkimustilanteessa. Jos nuoren kerronta spiraalista oli niukkaa, saattoi hän avata elämäänsä valokuvista puhuessaan laajemmin. Koska nuorten ilmaisutavat ovat vaihtelevia, voivat monipuoliset tutkimusmenetelmät tarjota vaihtoehtoisia kertomisen tapoja (Jokinen \& Pirskanen 2015, 47).

Tutkimukseen osallistui 20 nuorta (10 tyttöä ja 10 poikaa), jotka olivat iältään 14-20-vuotiaita. Tutkittavat tulivat erilaisista taustoista ja he kaikki asuivat Kanta-Hämeen maakunnassa pienellä 
paikkakunnalla. Haastattelut kestivät puolesta tunnista kahteen tuntiin ja ne tehtiin kodeissa, kahviloissa ja nuorisotilassa. Maakunnassa nuorten parissa työskentelevät henkilöt toimivat tärkeässä roolissa kysyessään paikallisilta nuorilta tutkimukseen osallistumisesta. Kaikki halukkaat nuoret olivat tervetulleita osallistumaan tutkimukseen. Osa nuorista osallistui tutkimukseen muiden nuorten kannustamina. Ennen haastattelua ja sen aikana neuvottelin osallistujien kanssa tutkimuksen säännöistä ja varmistin, että he olivat tietoisia siitä, mitä haastattelu koskee, miten se tapahtuu ja mitä heiltä odotetaan. Suurin osa nuorista osallistui paikallisen nuorisotilan toimintaan, josta heidät tavoitettiin tutkimukseen. Tutkimukseni ulkopuolelle jäivät ne paikkakunnan nuoret, jotka olivat täysin koulutuksen ja työn ulkopuolella. Tutkimustulokset kertovat pikkupaikkakunnan kontekstissa elävistä nuorista. Tämä konteksti raamittaa nuorten mahdollisuuksia valita esimerkiksi harrastuksia tai tulevaa opiskelupaikkaa.

Tutkimusaineiston analyysin tukena käytin ATLAS.ti -ohjelmaa, joka mahdollisti moninaisen aineiston rinnakkaisen tarkastelun. Vaikka analyysissäni kiinnitin erityisesti huomiota nuoren puheeseen, helpotti visuaalinen aineisto nuoren kerronnan ymmärtämistä ja analyysin syventämistä. Analyysitapana oli nuorten narratiivien aineistolähtöinen sisällönanalyysi. Analyysini on kaksiosainen. Ensimmäisessä vaiheessa analysoin nuorten kerronnan pohjalta, mitkä ovat heidän elämänkulkujensa käännekohtia. Analyysin toisessa osassa tarkastelin käännekohtia toimijuuden tunnon näkökulmasta. Aineistolähtöisen analyysin aluksi etsin aineistosta kuvauksia tapahtumista, hetkistä, kohtaamisista, ihmissuhteista ja siirtymistä, jotka nuorten puheessa muuttivat heitä tai heidän elämänsä suuntaa toimien elämänkulun käännekohtina. Nämä kertomukset liittyivät esimerkiksi muutoksiin ihmissuhteissa, opiskelujen aloittamiseen, läheisen sairastumiseen tai nuoren kokemukseen itsensä voittamisesta. Ilmaisujen pohjalta aloin muodostaa koodeja, joita nimesin muun muassa nuoren itsensä käyttämien käsitteiden mukaisesti, kuten seurustelun aloittaminen, kolari ja masennukseen sairastuminen.Aineiston koodaamisen jälkeen ryhmittelin koodeja ja muodostin niistä perheitä. Esimerkiksi koodit tapaturma, sairastuminen ja läheisen menettäminen saivat yhteisen kategorisen nimen yllättävät elämäntapahtumat. Lopuksi muodostin aineistosta pääluokkia, joita ovat: Sosiaaliset käännekohdat, Institutionaaliset käännekohdat, Sattumanvaraiset käännekohdat ja Voimaantumisen käännekohdat. Esittelen näitä käännekohtia yksityiskohtaisemmin artikkelin tulosluvuissa.

Seuraavaksi analysoin, millaisena nuoret kokivat mahdollisuutensa valintojen tekemiseen elämänkulun käännekohdissa. Esitän analyysin kulun seuraavan taulukon avulla. 
Taulukko 1. Analyysin kulku.

\begin{tabular}{|c|c|c|c|c|}
\hline $\begin{array}{l}\mathbf{K} \\
\ddot{a} \\
\ddot{a} \\
\mathbf{n} \\
\mathbf{n} \\
\mathrm{e} \\
\mathrm{k} \\
\mathbf{0} \\
\mathbf{h} \\
\mathrm{d} \\
\mathbf{a} \\
\mathbf{t}\end{array}$ & 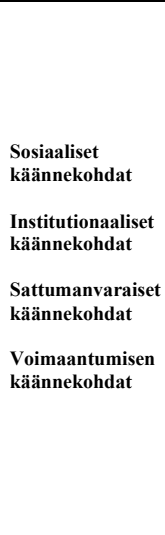 & $\begin{array}{l}\text { "Että mun tarvis, että mä oisin } \\
\text { parempi, mun pitäis polttaa } \\
\text { tupakkaa. Ja just, kun mun } \\
\text { kaverit seurustelee ja mä en } \\
\text { seurustele ja ehkä semmosissa } \\
\text { asioissa tuntuu, että mä tunnen } \\
\text { itteni huonommaks tai } \\
\text { näkymättömäks." } \\
\text { ”Ehkä mä sen itekin tiedän ja } \\
\text { tiedostan, mutta se että vaikka } \\
\text { ois taitoa ja tavallaan } \\
\text { potentiaalia, mutta jos ei } \\
\text { tavallaan tunne sitä omaks } \\
\text { alaks tai tunne sitä, että on oma } \\
\text { juttunsa, niin ei sieltä niin } \\
\text { hirveesti haluu panostaa." } \\
\text { "Musta tuntu välillä että mä en } \\
\text { kuulunu siihen et mä olin just } \\
\text { niissä leikeissä et laitettiin aina } \\
\text { siihen johonki rooliin mihin mä } \\
\text { en ois halunnu itte." }\end{array}$ & $\begin{array}{l}\text { Sosiaaliset suhteet: } \\
\text { Luottamuksellinen } \\
\text { vastuu/liiallinen vastuu, huoli } \\
\text { läheisistä, kuulumisen/yksin } \\
\text { jäämisen kokemus, arvostus, } \\
\text { kokemus tasavertaisuudesta } \\
\text { Valinnanmahdollisuus: } \\
\text { Mahdollisuus/mahdottomuus } \\
\text { vaikuttaa, kokemus kuulluksi } \\
\text { tulemisesta, omat valinnat } \\
\text { suhteessa toisten valintoihin } \\
\\
\text { Identiteetti: } \\
\begin{array}{l}\text { Itseluottamus/itseluottamuksen } \\
\text { puute, rooli -odotukset, rohkeus } \\
\text { olla oma itsensä, onnistumisen } \\
\text { ja innostumisen kokemukset }\end{array}\end{array}$ & $\begin{array}{l}\text { Kokemus sosiaalisesta } \\
\text { tuesta, vastuusta ja } \\
\text { yhteenkuuluvuudesta } \\
\text { elämänkulun } \\
\text { käännekohdissa } \\
\text { Autonomian } \\
\text { kokemukset } \\
\text { elämänkulun } \\
\text { käännekohdissa } \\
\text { Minäpystyvyys } \\
\text { elämänkulun } \\
\text { käännekohdissa }\end{array}$ \\
\hline
\end{tabular}

Etsin aineistosta ilmaisuja niistä asioista, jotka tukivat tai heikensivät nuoren toimijuuden tuntoa eli kokemusta mahdollisuuksista vaikuttaa, valita ja toimia toisin elämänkulun moninaisissa käännekohdissa. Nuorten ilmaukset liittyivät muun muassa erilaisiin rooleihin, joita heille tarjottiin ulkoapäin. Esimerkiksi kokemus ulkopuolisuudesta saattoi syntyä paineesta mukautua nuorelle epäluontevaan rooliin. Samoin kuin analyysini ensimmäisessä osassa, muodostin ilmaisujen pohjalta sisällöllisiä koodeja, kuten kokemukset tasavertaisuudesta, kuulluksi tulemisesta ja rohkeudesta olla oma itsensä. Myöhemmin analyysissa yhdistelin koodien aihepiirejä, jotka liittyivät kysymyksiin sosiaalisista suhteista, valinnanmahdollisuuksista ja identiteeteistä. Aihepiirien pohjalta syntyivät analyysin pääluokat, joita ovat 1. kokemus sosiaalisesta tuesta, vastuusta ja yhteenkuuluvuudesta elämänkulun käännekohdissa, 2. autonomian kokemukset elämänkulun käännekohdissa ja 3. minäpystyvyys elämänkulun käänne- kohdissa. Tulosluvut rakentuvat näiden pääluokkien mukaisesti.

\section{TUtKIMUKSEN EeTtISIÄ HUOMIOITA}

Tutkimuksen osallistujista suurin osa (18 nuorta) oli alaikäisiä ja kaksi heistä vielä 14-vuotiaita. Läpi tutkimuksen olen pyrkinyt huomioimaan nuorten iän. Tutkimusaiheeni, elämänkulkujen käännekohtien ja toimijuuden tunnon tarkasteleminen, vaati minulta sensitiivistä tutkimusotetta, sillä kerronnan hetkellä nuori saattaa paljastaa elämästään vaikeita ja kipeitä asioita (Lee 1993; Kallinen ym. 2015). Tällä tarkoitan luottamuksellista ja turvallista läsnäoloa haastatteluissa sekä sensitiivisyyttä ja vastuullisuutta tutkimuksen suunnittelussa ja julkaisuissa.

Jokainen tutkimukseen osallistunut allekirjoitti kirjallisen suostumuksen. Kysyin nuoren oman suostumuksen tutkimukseen osallistumiseen ja korostin, että tutkimuksessa mukana oleminen 
pohjautuu vapaaehtoisuuteen ja nuori voi halutessaan perua osallistumisensa. Varmistin, saako nuoren spiraalia ja kuvia käyttää tutkimusjulkaisuissa. Lisäksi pyysin alle 15-vuotiaiden haastateltavien huoltajilta luvan lapsensa tutkimukseen osallistumiseen.

Visuaaliseen tutkimusaineistoon liittyy erityisiä eettisiä huomioita. Yksityisyyttä käsittelevät kysymykset ovat visuaalisen tutkimuksen eettisen pohdinnan ytimessä. Spiraaleissa ja etenkin valokuvissa on yksityiskohtia, joista haastateltavat saatettaisiin tunnistaa. Nuorten yksityisyyden suojelemiseksi olen julkaisuissani poistanut spiraaleista tunnistettavuutta helpottavia nimiä, paikkakuntia tai päivämääriä. (Wiles ym. 2008, 22-23.) Tutkittavien henkilöllisyyden suojelemiseksi päädyin jättämään nuorten valokuvat artikkelista pois kokonaan.

\section{SOSIAALINEN TUKI, VASTUU JA YHTEENKUULUVUUS ELÄMÄNKULUN KÄÄNNEKOHDISSA}

Nuoren toimijuuden tunto liittyy kokemuksiin sosiaalisesta tuesta, vastuusta ja yhteenkuuluvuudesta toisten ihmisten kanssa. Moninaiset vuorovaikutussuhteet voivat joko vahvistaa tai heikentää nuoren toimijuuden tuntoa (Gordon 2005). Sosiaaliset suhteet ja toimintaympäristöt ovat merkittävästi esillä nuorten kerronnassa heidän tekemistään spiraaleista ja valokuvista. Perheenjäsenten lisäksi tärkeitä suhteita nuorille ovat ystävät, seurustelukumppanit, sukulaiset, kummilapset ja koulu- ja harrastusyhteisöt sekä perheen nykyiset ja edesmenneet lemmikkieläimet. Nuorten elämän käännekohdat liittyvät usein toisiin ihmisiin. Tällaisia sosiaalisia käännekohtia ovat muun muassa vanhempien ero, seurustelun aloittaminen sekä ystävyyssuhteiden solminen, mutta myös ihmissuhteiden päättyminen. Nuoret jakavat kokemuksiaan muuttuneista rooleistaan elämänkulun käännekohdissa. Esimerkiksi pienemmän sisaruksen syntymä voi muuttaa nuoren kokemusta omasta roolistaan perheessä ja vastuu nuoremmista sisaruksista voi vahvistaa toimijuuden tuntoa. Vastuu voi näyttäytyä myönteisenä tunteena luottamuksesta, mutta myös toimijuuden tuntoa heikentävänä kokemuksena, kun vastuuta koetaan olevan liikaa (H17).

Kuviossa 1 on 15-vuotiaan tytön (H17) tekemä elämänspiraali. Nuori on kirjoittanut elämänspiraaliinsa vanhempiensa erosta ja heidän uusista parisuhteistaan. Nuori kertoo, miten vanhempien ero on vaikuttanut hänen elämäänsä. Nuorelle vanhempien ero on ollut elämänkulun käännekohta, joka on synnyttänyt kokemuksen vastuunkantajan roolista. 


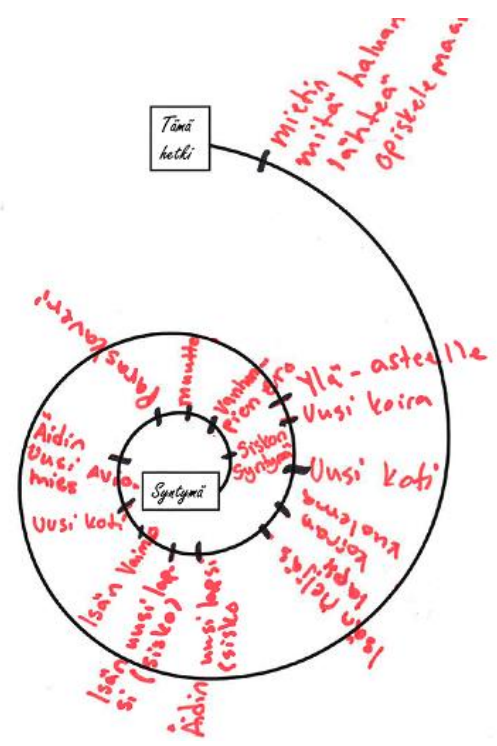

Kuvio 1. Elämänspiraali, tyttö 15v. (H17).

Tyttö: Me ollaan vähän siinä välissä sillai, kun ne ei oikein. Kyl ne toimeen tulee jotenki, mutta ne ei hirveen läheisiä. Me ollaan siinä välissä. Yritetään kommunikoida. Olla semmonen välikäsi. Siitä välillä syntyy semmosta ongelmaa ja ulkopuolisuutta. (H17, 15v.)

Nuori (H17) kokee olevansa "välikäsi" suhteessa eronneisiin vanhempiinsa. Nuori ei siis aina itse voi vaikuttaa elämänkulkunsa rakentumiseen, sillä linkittyvät elämät, tässä tapauksessa vanhempien valinnat, vaikuttavat tytön elämäntilanteeseen ja toimijuuden tuntoon. Tytön kertomus alleviivaa erilaisten ryhmäjäsenyyksien vaikutuksen identiteettiin (Hall 2002) ja kokemukseen muuttuneesta roolista, joka on haastateltavalle haasteellinen. Nuori kertoo, ettei hän haluaisi olla vanhempiensa välikätenä kykenemättä puuttumaan tilanteeseen. Kykenemättömyys puuttua vallalla oleviin tilanteiseen voi heikentää nuoren toimijuuden tuntoa. Nuori (H17) kokee vastuuta suhteessa vanhempiinsa ja sisarukseensa. Kykenemättömyys valita ja puuttua tilanteeseen liittyy myös nuoren ikään, sillä alaikäisenä esimerkiksi poismuutto kotoa ei ole välttämättä mahdollista.

Nuorten liikkuminen kahden perheen välillä on voinut johtaa kokemuksiin välien etääntymisestä, mutta myös niiden paranemisesta suhteessa vanhempiin.

Poika: Nyt mä en oo ollu pariin kuukauteen, puhelimes ollaa vaa juteltu. Ei oikei huvita mennä, siellä mulla on kaks pikkuveljeä ja niil menee aikaa niitten hoitamiseen. Ja muutenkin on kivempi olla kavereitten kaa ku olla sitten iskällä viikonloppu. (H12, 15v.)

Tyttö: Viime kesänä, eli silleen vuos sitten, vähän yli. Niin vanhemmat eros, et se on 
taas silleen, periaatteessa mulle iso ja tärkee asia, koska iskän ja mun välit ei ollu mitenkään hirveen hyvät. Aina oli vähän semmossii, kinaa ja tämmöstä. Ja sit kun ne eros niin meil iskän kaa tuli jokskin aikaa tosi hyvät välit. Silleen kun ei kotona kinasteltu, eikä asuttu saman katon alla niin aina kysyttiin kuulumisia ja sen semmosta. (H6, 17v.)

Vanhempien ero nuoren elämän käännekohtana voi johtaa kokemukseen välien lähentymisestä, mutta myös etääntymisestä. Nuori voi joissakin tilanteissa kokea eron myönteisenä asiana, sillä se on voinut lisätä yhteenkuuluvuuden kokemusta suhteessa vanhempiin tai helpottaa kodin riitaista ilmapiiriä. Toimijuuden tunnon näkökulmasta kahden kodin välillä liikkuminen voi tarkoittaa nuorelle valinnanmahdollisuutta siitä, kuinka usein hän haluaa nähdä vanhempiaan (H12).

Monet haastateltavat kuvaavat parhaan ystävän kohtaamista elämän käännekohdaksi. Ystävät ovat esillä niin nuorten spiraaleissa kuin valokuvissa. Nuoret kertovat, kuinka jotkut ystävyyssuhteet ovat elämänkulun aikana katkenneet ja kaveriporukat vaihtuneet esimerkiksi uusien harrastusten ja muuttojen myötä. Haastateltavat kuvailevat omaa rooliaan kaveriporukoissa.

Tyttö: No, kyllähän sitä vois vaikuttaa vaikka mihin, jos vaan osais aukasta suunsa. Mä oon vähän semmonen nössykkä, että meen vähän muitten mukana joissakin asioissa ja liian kiltti, että ei oikein tuu sanottua, vaikka ehkä tarviiskin joskus jostain asioista. Et en mä jotenkin rupee änkeemään omaa mielipidettäni. Sit siit tulis vaan turhaa semmosta sananharkkaa ja välttelyä ja mä yritän välttää sitä viimeseen asti, kun en mä halua tuhlata mun energiaa semmoseen, et mä rupeen tappelemaan jostain. $(\mathrm{H} 3,20 v$.

Nuori (H3) kertoo, ettei välttämättä pysty aina sanomaan kaveriporukassaan suoraan, mitä ajattelee. Tyttö kertoo välttävänsä ristiriitoja. Näin ollen myös vaikeneminen voi olla nuoren oma valinta. Nuoren toimijuuden tunto kaveriporukassa voi olla samanaikaisesti heikkoa ja vahvaa. Ristiriitojen pelossa nuori ei välttämättä kerro ajatuksiaan ääneen. Toisaalta vaikeneminen nuoren omana valintana osoittaa toimijuuden tuntoa, jossa ulospäin näyttäytyvä passiivisuus kätkee sisälleen sisäistä toimijuuden kokemusta (Juvonen 2014, 93).

Yksinäisyyden ja yksin olemisen kokemukset toistuvat monen nuoren puheessa. Yksinäisyyden ja ulkopuolisuuden kokemukset voivat heikentää nuoren kokemusta itsestään toimijana, sillä ulkopuolelle jääminen ei ole aina nuoren itsensä valinta. Tällöin nuori voi kyseenalaistaa omaa arvokkuuttaan. (Juntunen 2019.)

Haastateltava (H7) nostaa elämänspiraalista kertoessaan esille elämänsä aikana solmitut ystävyyssuhteet ja harrastukset, joiden kautta hän on saanut kavereita. Kerronnassaan nuori palaa varhaislapsuuteensa ja silloin kokemaansa yksinäisyyden tunteeseen. Esikoulu näyttäytyy nuoren puheessa elämänkulun käännekohtana, sillä silloin hän on alkanut solmia ystävyyssuhteita ja kokenut yksinäisyytensä helpottaneen. Pojan puheessa korostuvat sosiaaliset suhteet ja niiden merkitys arjessa sekä elämän mielekkyyden kokemisessa. Nuoren mukaan lapsuudessa koettu yksinäisyys on vaikuttanut siihen, miksi 


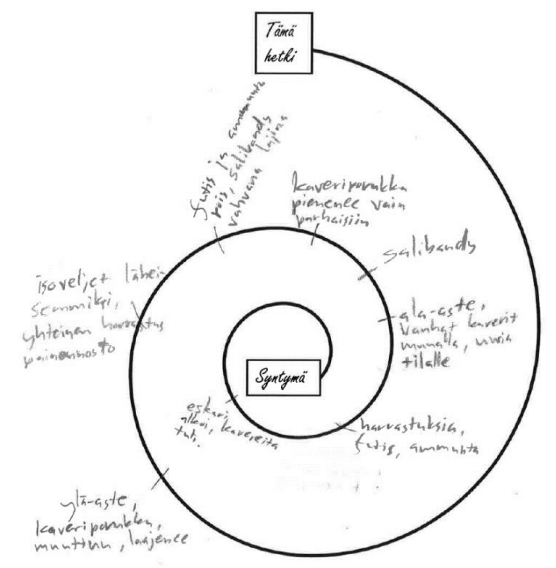

Kuvio 2. Elämänspiraali, poika 15v. (H7).

kaverit ja kuuluminen harrastusyhteisöihin ovat hänelle tärkeitä haastatteluhetkellä ja myös tulevassa elämänkulussa. Vaikka kokemus yksin jäämisestä voi heikentää toimijuuden tuntoa, voi se myös synnyttää sisäistä tunnetta halusta solmia ystävyyssuhteita ja olla osa jotakin. Kuulumisen kokemus yhdistyy nuoren (H7) kerronnassa toimijuuden tuntoon, joka syntyy vertaissuhteessa toisiin ihmisiin.

Poika: No kaikkihan me ollaan aika tasavertasia siinä, et ei kukaan oo mitenkään johtava eikä kukaan syrji toisia elikkä kaikki ollaan siinä ihan yhdessä samassa joukkueessa, että kaikki ollaan kavereita. (H7, 15v.)

Edellä nuori kertoo joukkueesta, jossa hän pelaa. Yhteenkuuluvuuden kokemus liittyy ajatukseen tasavertaisuudesta. Tasavertaisessa joukkueessa nuori kokee voivansa vaikuttaa ja olla yhdenvertainen joukkuetovereidensa kanssa. Näin ollen kokemus tasavertaisuudesta voi vahvistaa toimijuuden tuntoa.

\section{Autonomian kokemukset \\ ELÄMÄNKULUN KÄÄNNEKOHDISSA}

Kokemus autonomiasta näyttäytyy keskeisenä toimijuuden tunnon ulottuvuutena nuorten elämänkulun käännekohdissa. Autonominen toimijuus tulee lähelle toimijuuden tunnon ajatusta. Molemmissa on kyse nuoren kokemuksesta hänen mahdollisuuksistaan vaikuttaa omaan elämänkulkuun ja tehdä valintoja. (Gordon 2005; Hass ym 2014.) Nuorten autonomiaan ja sen puutteeseen liittyvät kokemukset tulevat esille niin sosiaalisissa, institutionaalisissa, sattumanvaraisissa kuin voimaantumisenkin käännekohdissa.

Institutionaaliset käännekohdat ja erityisesti kasvatukselliset instituutiot, kuten päiväkoti ja koulu ovat esillä nuorten kerronnassa. Suurin osa nuorista käy läpi elämänspiraalissaan koulutuspolkuaan, aina esikoulusta haastatteluhetken elämäntilanteeseen asti. Monelle nuorelle esikouluun meneminen, yläkouluun siirtyminen ja 
toisen asteen opintojen aloittaminen ovat olleet elämänkulun institutionaalisia käännekohtia. Nämä institutionaaliset käännekohdat ovat samalla myös sosiaalisia käännekohtia, sillä nuoren sosiaaliset verkostot ovat voineet muuttua.

Poika: Sitten 13-vuotiaana siirryin yläasteelle, niin se oli tosi jännää aikaa, sitä mä ootin tosi paljon, elämä munttu tosi paljon, todella paljon, huomattavasti ja elämäntavat muuttu. Kaveripiiri vaihtu ja oli vähän, se elämä oli paljon rankempaa ja silleen huoletonta, mutta omaa vastuuta kouluhommissa oli sitten enemmän. (H13, 15v.)

Tyttö: Niin ja sitten ysiluokka alko ja mä laitoin tohon, että mua pelotti, koska kyllä mua vähän pelotti mennä yheksännelle luokalle, koska kyllä mä tiedän, että tän luokan jälkeen pitää päättää mitä tekee ja mä en tiedä yhtäan. Mua pelottaa se ja täs on vaan miettinyt, että mitä mä teen tulevaisuudessa. (H10, 15v.)

Edellä nuoret (H13 ja H10) kertovat, millaisia ajatuksia yläkouluun siirtyminen ja toisen asteen opintojen aloittaminen heissä herättävät. Nuorten kertomuksissa nivelvaiheista korostuu vastuu omasta toimijuudesta. Institutionaaliset käännekohdat ja niihin liittyvät valinnat herättävät nuorissa myös stressiä ja jopa pelkoa. Tyttö (H10) kertoo pelostaan liittyen peruskoulun päättymiseen ja tulevan opiskelupaikan valintaan. Usean haastateltavan puheesta nousee ajatus siitä, että yläkoulussa elämän suuntaviivat tulisivat olla selvillä. Tämä paine tulee toisilta nuorilta, kotoa, koulusta tai julkisesta keskustelusta. Kokemus siitä, että nuoren tulisi tehdä päätöksiä tulevaan elämänkulkuunsa liittyen voi vaikuttaa toimijuuden tun- toon heikentävästi. Kaikki nuoret eivät koe olevansa vielä valmiita tekemään suuria päätöksiä tulevaa elämänkulkuaan koskien. Myös epävarmuuden esille nostaminen voi olla joillekin nuorille vaikeaa.

Nuoret tasapainoilevat ihanteellisen institutionaalisen polun ja oman näköisen elämänkulun rakentamisen välillä. Haastateltavat hakevat kerronnassaan merkityksiä tekemilleen valinnoille ja heidän toimijuuden tuntonsa koulutuksellisten ja ammatillisten valintojen suhteen vaihtelee. Toinen kokee itse valinneensa oman alansa, kun taas toinen kertoo pikemminkin päätyneensä opiskelupaikkaansa. Opiskelupaikkaan päätyminen voi johtua esimerkiksi kavereiden valinnoista, sillä nuoret voivat valita opiskelupaikkansa sen perusteella, mihin ystävät ovat hakeneet (Juntunen 2019).

Nuoret tulevat pieneltä paikkakunnalta, jossa lukio on ainut mahdollinen jatko-opintomahdollisuus peruskoulun jälkeen. Haastateltavat pohtivat omia tavoitteitaan suhteessa tarjolla oleviin resursseihin. Nuori voi esimerkiksi kokea toimijuuden tuntonsa heikoksi silloin, kun hän jää paikalliseen lukioon siitä syystä, ettei hänen tarvitsisi muuttaa opintojen perässä muualle. Nuorten koulutuksellisiin ja ammatillisiin valintoihin liittyy myös ulkoapäin tulevia odotuksia. Toimijuuden tunto näissä valinnoissa voi tarkoittaa myös nuoren kokemusta mahdollisuudesta valita toisin kuin häneltä odotetaan. Tällaisesta tilanteesta on kyse esimerkiksi silloin, kun vanhemmat toivovat nuoren menevän lukioon, mutta nuori itse valitsee ammatillisen koulutuksen. Sosiaaliset rakenteet vaikuttavat ihmisen 
kokemukseen hänen mahdollisuuksistaan valita elämänkulun erilaisissa käännekohdissa ylläpitäen erilaisia ihanteita ja normeja. Toimijuuden tunto voi olla kokemusta myös toisin valitsemisesta. Ihminen voi toimijuudellaan ja kokemuksella toisin valitsemisesta haastaa ulkopuolelta määriteltyjä toimijuuden rajoja. (Juvonen 2015, 92.)

Rippikoulu on yksi nuorten elämän merkittävä institutionaalinen ja sosiaalinen käännekohta. Puolet nuorista on merkinnyt elämänspiraaleihinsa rippikoulun yhdeksi elämänkulun käännekohdaksi. Jotkut nuoret ovat tuoneet mukanaan valokuvia konfirmaatiopäivästä. Näin nuorten elämänkulut liittyvät ainakin rippikoulun ajaksi Evankelisluterilaisen kirkon instituutioon. Haastateltavista 19 on käynyt tai aikoo käydä rippikoulun. Vuonna 2016 suomalaisnuorten 15-vuotiaiden ikäluokasta jopa 85,8 prosenttia osallistui rippikouluun sukupuoleen katsomatta (Sakasti, Tilastot, Varhaiskasvatus-, nuoriso- ja rippikoulutyö). Rippikoulun tutkiminen toimijuuden tunnon näkökulmasta yhtenä nuoren elämän käännekohtana voi tarjota vastauksia rippikoulun suosiolle. Vaikka haastateltavat kertovat kontrollista ja säännöistä, joihin heitä velvoitetaan rippikoulussa sitoutumaan, on rippikoulu kokemuksena myös itsenäisyyteen ja omaan ajatteluun kannustava. Toiset kertovat yllättyneensä siitä, että kristinuskon teemojen käsittely rippikoulussa ei tarkoittanutkaan uskonnon "tuputtamista". Usealla nuorella on ennakkoluuloja rippikoulun käymiseen liittyen. Nuorten puheessa kokemus osoittautuu kuitenkin useimmiten myönteiseksi, sillä nuoren omat ennakkoluulot ovat rippikoulun aikana murentuneet. Nuoret korostavat ennen kaikkea rippikoulun sosiaalista ulottuvuutta.

Tyttö: Mun mielestä ripari oli tosi mukava. Mulla oli kyllä ennakkoluuloja siitä, koska tiesin ketä ihmisiä siellä on. Oli semmosia ihmisiä, jotka oli mun luokalla ja kenen kaa ei oikeestaan oo koskaan tullu niin hyvin toimeen. Pakostihan siinä riparilla joutuu puhuu. Olla yhtä porukkaa. $(H 14,17 v$.)

Monet haastateltavista kertovat saaneensa uusia kavereita rippikoulusta. Nuorten väliset hierarkiat ovat hälventyneet yhteisen leiriviikon aikana (H14). Nuorille rippikoulun käyminen on tärkeä osa paikallista nuorisokulttuuria ja sitä pidetään eräänlaisena vedenjakajana lapsuuden ja nuoruuden välillä (esim. Porkka 2016, 92).

Kukaan nuorista ei kertonut kokevansa kotoa tulevaa painostusta rippikoulun käymiseen, vaan nuoret mielsivät sen omaksi valinnaksi. Nuorten kokemus rippikoulusta elämänkulun käännekohtana vaikuttaa olevan yhteydessä vahvaan toimijuuden tuntoon. Kun peruskoulua pidetään velvollisuutena, nähdään rippikoulu nuoren itsensä valintana. Rippikoulun ja konfirmaation jälkeen nuori voi valita suhteensa kirkkoon. Jotkut nuorista ovat toimineet tai aikovat tulevaisuudessa toimia isosina. Toisten puheessa suhde kirkkoon ja sen toimintaan jatkuu samankaltaisena kuin ennen rippikoulua, sopivan etäällä. Nuorten puheessa kirkko instituutiona näyttäytyy kuitenkin myös tulevan elämänkulun käännekohdissa, sillä useimmat nuoret haaveilevat kirkkohäistä ja omien lasten kastamisesta.

Poika: Mä en ollenkaan tiiä, että jos mä en ees eroo kirkosta sitte jossai kohtaa, ni sitte 
ku menee kummiski naimisii ni voi käydä iha kirkkohäissä $(H 12,15 v$.)

Aiemman tutkimuksen mukaan ulkoiset tekijät, kuten mahdollisuus kummina toimimiseen ja kirkolliseen vihkimiseen, ovat nuorille tärkeitä syitä rippikoulun käymiseen (Porkka 2017, 168). Tämän artikkelin tutkimustulokset vahvistavat ulkoisten tekijöiden merkitystä rippikoulun käymisessä.

\section{MINÄPYSTYVYYS ELÄMÄNKULUN KÄÄNNEKOHDISSA}

Nuorten kokemukset onnistumisesta, innostumisesta, itsensä voittamisesta ja selviytymisestä voivat vahvistaa toimijuuden tuntoa. Myönteiset kokemukset voivat toimia toimijuuden tuntoa lujittavina asioina (Gordon 2005). Nuoret kertovat haastatteluissa elämänkulun käännekohdista, jotka rohkaisevat nuorta toimimaan omien tavoitteidensa ja toiveidensa mukaisesti. Nimitän nuoren käsitystä selviytyä elämänkulun erilaisista tehtävistä minäpystyvyydeksi, jolla tarkoitetaan ihmisen luottamusta omiin kykyihinsä elämänkulun moninaisissa tilanteissa (Bandura 1997).

Nuoret kertovat sattumanvaraisista elämänkulun käännekohdista. Tällaisia käännekohtia ovat muun muassa nuorensa itsensä tai läheisen sairastuminen, onnettomuudet ja kuolemantapaukset. Myös muutokset ihmissuhteissa tapahtuvat nuorten mukaan usein yllättäen. Yllättävät elämäntapahtumat voivat aiheuttaa suuria muutoksia ihmisen elämässä (Oravala \& Rönkä 1999). Nuoret jakavat kokemuksiaan siitä, kuinka elämä voi muuttua esimerkiksi läheisen sairastuessa tai onnettomuuden kohdatessa. Nuoret eivät voi vaikuttaa elämänkulun sattumanvaraisiin tapahtumiin ja näin ollen toimijuuden tunto voidaan kokea valinnanmahdollisuuden näkökulmasta heikoksi. Nuorten puheessa korostuu kuitenkin oman suhtautumistavan vaikutus yllättävien käännekohtien edessä. Nuoret ovat valmiita kantamaan vastuuta läheisistään vaikeissa elämäntilanteissa ja he näkevät, että oma asenne on ratkaisevassa roolissa selviytymisessä.

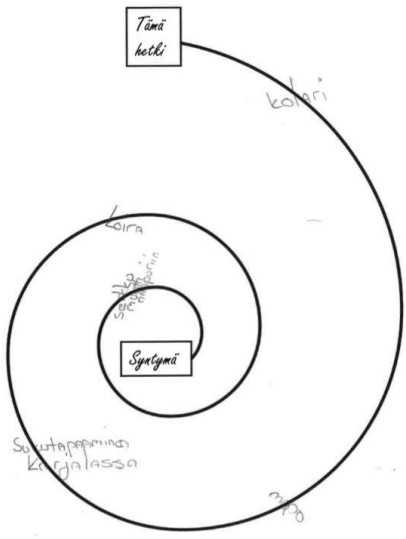

Kuvio 3. Elämänspiraali, poika 15v. (H2). 
Poika: Vuos sitten sattu kolari, kun oltiin menossa mummin synttäreille. Se oli merkittävä hetki. Isä ajo autoo ja näki, kun vastaantuleva menetti trailerin hallinnan. Se oli farmariauto ja faija hiljens siihen sitten ja koitti mennä penkan puolelle, mutta se iski aika nätisti vanteeseen. Mulla on täydellinen kuva siitä silmissä vieläkin. (H2, 15v.)

Poika: Kyl se ainakin muutti vielä lähemmiks välejä, eikä ne kuitenkaan niin erkaantuneet ollukaan eikä ne todellakaan nytten ole. $(\mathrm{H} 2,15 v$.)

Edellä nuori (H2) kertoo kolarista, johon hän on joutunut perheensä kanssa. Haastateltava on merkannut tapahtuman elämänspiraaliinsa. Nuoren mukaan kolari on lähentänyt perheenjäsenten keskinäisiä välejä. Haastateltava kertoo, että ilman kolaria perheenjäsenet eivät olisi toisilleen yhtä läheisiä kuin nuori kokee heidän olevan. Yllättävät elämäntapahtumat voivat kirkastaa elämän tärkeimpiä asioita ja näin vaikuttaa nuoren valintoihin. Arvojen suhde toimijuuden tuntoon on keskeinen, sillä nuoret rakentavat elämänkulkuaan ja käsitystään hyvästä elämästä suhteessa niihin asioihin, jotka ovat heille tärkeitä (Häkkinen \& Salasuo 2016).Vieraiksi koetut arvot voivat heikentää toimijuuden tuntoa silloin, kun yksilö kokee toimivansa vastoin arvojaan (Ikonen 2018).

Moni nuori kertoo menettäneensä elämänkulun aikana jonkun itselleen tärkeän ihmisen tai lemmikkieläimen. Nuoret ovat merkanneet näitä hetkiä spiraaleihin, ja jotkut ovat tuoneet haastatteluun valokuvia jo edesmenneistä läheisistä tai lemmikeistä. Eräs nuori kertoo, kuinka hän on alkanut vierailla useammin leskeksi jääneen isoäitinsä luona. Toinen nuori puolestaan pohtii, kuinka voisi tukea ystäväänsä, jonka äiti on menehtynyt syöpään. Edellä poimitut esimerkit aineistosta osoittavat, kuinka yllättävä elämäntapahtuma voi herättää nuoressa kokemuksen vastuusta suhteessa hänelle tärkeisiin ihmisiin. Jotkut nuorista ovat seuranneet vierestä läheisen sairastumista. He kertovat, miten perheenjäsenen sairastuminen vaikuttaa koko perheeseen ja sen dynamiikkaan. Pelko läheisen menettämisestä voi lamauttaa nuoren toimijuuden tuntoa, jos nuori kokee, ettei hän voi vaikuttaa tilanteeseen. Toisaalta nuori voi yllättävissä ja haastavissa käännekohdissa osoittaa vahvaa toimijuuden tuntoa kantaessaan huolta läheisten voinnista.

Nuoren oma sairastuminen, sairauden kanssa elämään oppiminen tai siitä selviytyminen voivat heikentää, mutta myös vahvistaa, nuoren kokemusta itsestään toimijana.

Tyttö: Varmaa ilma sairautta en olisi tämmönen. Siis niinku nyt oon. Ja sit osaan eläytyä tai siis ymmärtää samassa tilanteessa olevia ihmisiä. $(H 5,16 v$.)

Poika: Kärsimyskin opettaa ihmistä. Sitä kautta sen oppiikin, että mitä se on oikeesti, kun on masentunut. Näkee sitä, että kuinka paljon paremmin nyt on sit. Masennuskin on ollut... Se on pitkälti liittynyt tohon kiusaamiseen. Siis vaikeeseen elämäntilanteeseen. Sit kun alkaa näkee sitä elämää, että se ei oo niinkään lopullista. (H4, 19v.)

Nuoret (H5 ja H4) ovat sairastaneet masennusta, jonka taustalla on heidän mukaansa aiemmat kokemukset kiusatuksi tulemisesta. Masennus vaikuttaa esimerkiksi heikkona itsetuntona, ve- 
täytymisenä kotiin ja arkuutena solmia kaverisuhteita. Kokemus sairastumisesta voi toimia myös itseymmärryksen perustana. Ilman haastavaa kokemusta nuori ei olisi se ihminen, joka hän tuntee olevansa. Aiemman tutkimuksen (Saarelainen 2017) mukaan nuoren sairastuminen voi johtaa kokemukseen sairaudesta osana identiteettiä, kuten myös tämän tutkimuksen tulokset osoittavat. Kokemus masennuksesta voi auttaa ymmärtämään paremmin toisia ihmisiä, jotka ovat kokeneet saman. Ajallisuuden näkökulma toimijuuden tuntoon on tärkeä, sillä nykyisyyden ymmärtäminen menneisyyden kokemusten avulla voi vahvistaa nuoren kokemusta itsestään toimijana. Haastava elämänkulun käännekohta voi johtaa vahvaan toimijuuden tuntoon, sillä selviytymisen kokemus on voinut osoittaa nuorelle hänen oman vahvuutensa.

Harrastuksen aloittaminen tai itsensä voittaminen haastavassa tilanteessa voivat tarkoittaa nuorelle elämänkulun käännekohtia. Voimaantumisen käännekohdat ovat niitä elämänkulun hetkiä, jotka vahvistavat nuoren tunnetta omista vahvuuksistaan, voimavaroistaan ja intohimoistaan. Voimaantuminen eli sisäinen voiman tunne on henkilökohtainen ja sosiaalinen prosessi, joka lähtee yksilöstä itsestään (Perkins \& Zimmerman 1995). Voimaantumisen käännekohdat ja niihin liittyvät kokemukset ovat yhteydessä nuoren minäpystyvyyteen ja itsetuntoon.

Tyttö: Se oli varmaan jotenkin silleen, että halusin ottaa selvää missä mun rajat on. Mihin mun ääni tai laulu riittää tai silleen, että mä halusin ottaa selvää kuinka hyvin mä pärjään tämmösessä. Kyllä mulla oli sil- leen just rohkeutta, että kyllä mä uskalsin olla yksin ja näin. (H1, 14v.)

Edellä nuori (H1) kertoo osallistumisestaan laulukilpailuun. Tyttö on merkinnyt kilpailun elämänspiraaliinsa ja toi mukanaan kuvan tilanteesta. Vaikka nuori ei omien sanojensa mukaan pärjännyt kisassa hyvin, on siihen osallistuminen ollut hänelle elämänkulun merkittävä käännekohta. Nuori on tyytyväinen itseensä, sillä osallistuminen vaati häneltä rohkeutta laulaa yksin lavalla. Nuori kertoo, että kokemus on lisännyt hänen luottamusta itseensä elämän eri osa-alueilla. Myönteinen kokemus elämänkulun käännekohtana voi vahvistaa nuoren toimijuuden tuntoa ja näkyä rohkeutena olla oma itsensä erilaisissa tilanteissa.

Voimaannuttavat käännekohdat ovat esillä nuorten tekemissä elämänspiraaleissa ja valokuvissa.

Tyttö: Mä otin sinisen just sen takia et se on mun lempiväri ja mä aattelin, et laitan sillä kaikkii positivisii muistoja mun elämästä ja sit henkilöitä. Sit noi kaks punasta eli eskari ja kesä 2012 on semmosia mistä mä en oo niin paljon tykänny. (H8, 17v.)

Edellä nuori (H8) kertoo, mikä merkitys on hänen valitsemillaan väreillä. Sininen on nuoren lempiväri ja se tarkoittaa elämänkulun positiivisia tapahtumia, punainen kuvastaa vaikeita hetkiä. Kesällä 2012 nuori on kokenut itsensä yksinäiseksi. Tyttö kertoo, että hänellä on ollut itsetuntoon liittyviä ongelmia, jotka nuoren mukaan kulkevat käsikädessä yksinäisyyden kokemuksen kanssa. Toimiminen paikallisessa nuorisovaltuustossa (Nuva) on nuoren mukaan kasvattanut hänen luottamusta itseensä. 


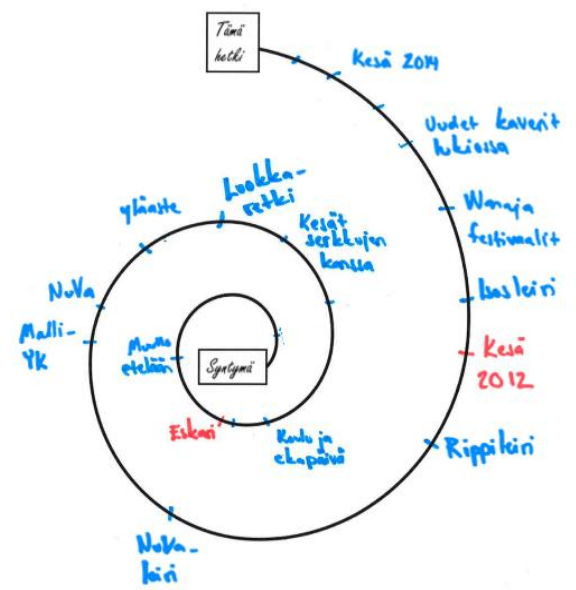

Kuvio 4. Elämänspiraali, tyttö 17v. (H8).

Tyttö: Mulla ei oo aina ollu hyvä itsetunto, musta tuntuu et se on parantunu koko ajan et mä uskallan olla enemmän oma itteni, et mun ei tarvii enää aatella niin paljon, et mitä muut ajattelee musta. Mä voin tehdä just niinkun mä ite haluan. Se vaan jotenkin tapahtu, en mä tiiä onks se Nuva, kun on joutunu puhuu ihmisten edessä, on saanu sitä varmuntta. $(\mathrm{H} 8,17 v$.)

Edellä oleva esimerkki osoittaa, millainen merkitys myönteisillä kokemuksilla voi olla nuoren itsetuntoon ja toimijuuden tuntoon. Nuori (H8) kertoo joutuneensa nuorisovaltuustossa puhumaan ihmisten edessä ja olemaan esillä. Voimaannuttavat kokemukset kasvattavat nuoren minäpystyvyyttä ja hän uskaltaa olla enemmän oma itsensä välittämättä muiden mielipiteistä. Nuori kertoo, ettei halua välttämättä tulevaisuudessa perustaa perhettä, vaikka "niin kuuluisi tehdä", vaan hän haluaa matkustella, oppia uutta ja tutustua ihmisiin. Toimijuuden tunto voi tarkoittaa nuorelle näkemystä omannäköisestä elämänkulusta sosiaalisista, kulttuurisista ja yhteiskunnallisista ihanteista ja normeista välittämättä.

\section{Pohdinta - KoHtI ELÄMÄNKULUN KÄÄNNEKOHTIEN POLITIIKKAA}

Tässä artikkelissa olen tutkinut 14-20-vuotiaiden nuorten elämänkulun käännekohtia toimijuuden tunnon näkökulmasta. Koska ihminen voi arvioida elämän käännekohtia ja niiden merkityksiä vasta myöhemmässä elämänkulussa, olen käyttänyt aineistonkeruun menetelmänä haastatteluiden lisäksi elämänspiraalia ja nuorten valokuvia. Spiraalien ja valokuvien avulla nuoret rakensivat elämästään haastattelutilanteessa syntyviä kertomuksia.

Tulokset osoittavat, ettei nuoren elämänkulun käännekohtia voi kategorisoida yksiselitteisesti, vaan ne liittyvät kiinteästi toisiinsa. Esimerkiksi institutionaaliset, sattumanvaraiset ja voimaantumisen käännekohdat tuovat mukanaan sosiaalisia muutoksia. Voimaantumisen käännekohta voi puolestaan liittyä yllättävään tai institutionaaliseen elämänkulun käännekohtaan. Vaikka ihmiselle on luontevaa tulkita käännekohdiksi ne tapahtumat, joihin hän kokee voivansa vaikuttaa (Clausen 
1995), osoittavat tämän tutkimuksen tulokset toimijuuden tunnon vaihtelevan käännekohdiksi mielletyissä elämänkulun tapahtumissa. Nuoret rakentavat kerronnassaan merkityssysteemejä, joissa käännekohdista löydetään moninaisia ulottuvuuksia. Käännekohtia ei voi tarkastella vain toimijuuden tuntoa vahvistavina tai heikentävinä kokemuksina. Usein nuori löytää käännekohdista niin valinnanmahdollisuuksia voimistavia kuin rajoittaviakin piirteitä.

Käännekohtien tavoin toimijuuden tunnon rakennusaineita ei voida tarkastella toisistaan erillisinä. Kokemukset sosiaalisesta tuesta, autonomiasta ja minäpystyvyydestä liittyvät toisiinsa. Kokemukset sosiaalisesta tuesta ja yhteenkuuluvuudesta tai niiden puutteesta voivat vahvistaa, mutta myös heikentää autonomian ja minäpystyvyyden tunteita. Kokemus autonomiasta voi puolestaan vahvistaa minäpystyvyyden kokemusta. Tulokset tukevat ajatusta toimijuuden tunnon ja elämänkulun käännekohtien vastavuoroisesta suhteesta. Käännekohdat muovaavat toimijuuden tuntoa sitä vahvistaen tai heikentäen riippuen siitä, millaisia merkityksiä nuori antaa niille kerronnassaan. Nuoren toimijuuden tunto voi määritellä suhtautumista elämään elämänkulun moninaisten käännekohtien edessä.

Elämänkulun ja siihen liittyvien käännekohtien tarkasteleminen tarjoaa toimijuuden tunnon tutkimiseen ajallisuuden ulottuvuuden. Menneisyyden ja siihen liittyvien valintojen pohtiminen voi toimia itseymmärryksen välineenä nykyisyydessä ja tulevassa elämänkulussa. Vaikka nuori on voinut nähdä käännekohtaan liittyvän elämän- tilanteensa toimijuuden tunnon näkökulmasta haastavana, voi juuri ajallisuus eli nykyisyyden ymmärtäminen menneisyyden avulla tarjota avaimia omien valintojen pohtimiseen. Vaikka elämänkulun tapahtumista seuraisi negatiivisia asioita, voivat nämä seuraukset tulevassa elämänkulussa saada myönteisiä merkityksiä (Elder 1998; Rutter 1996). Nuori voi kokea valinnanmahdottomuutta elämänkulun erilaisissa käännekohdissa, mutta myöhemmin kerronnan hetkellä hän voi ymmärtää, että esimerkiksi oma asennoituminen suhteessa käännekohtien tuomiin muutoksiin toimii nuoren valintana ja tuntona toimijuudesta. Näin käännekohtaan liittyvä toimijuuden tunto voi muuttua nuoren elämänkulussa.

Nuoren elämän käännekohtien tutkiminen juuri toimijuuden tunnon käsitteen avulla on tärkeää, sillä keskustelu nuorten toimijuudesta liittyy usein ulospäin havaittavaan toimijuuteen, aktiivisuuteen ja osallisuuteen (Kiilakoski 2012). Näin nuoren sisäinen toimijuuden kokemus voi hukkua toimijuuden ihanteiden alle. Toimijuuden tunto herättää kysymään, miten nuori itse kokee toimijuutensa ja mahdollisuutensa valita. Seuraavassa kuviossa havainnollistan toimijuuden tuntoa elämänkulun käännekohdissa suhteessa toimijuuden toteuttamiseen, sosiaalisiin, kulttuurisiin ja yhteiskunnallisiin ympäristöihin sekä ihanteisiin aktiivisesta toimijuudesta ja elämänkaaripoliittisesta nuoruudesta.

Suomalainen nuorisopolitiikka painottaa siirtymien merkitystä nuoren elämänkaaren jaksottamisessa (Suurpää 2009). Tulokset viittaavat siihen, ettei pelkkien siirtymien ja erilaisiin palve- 


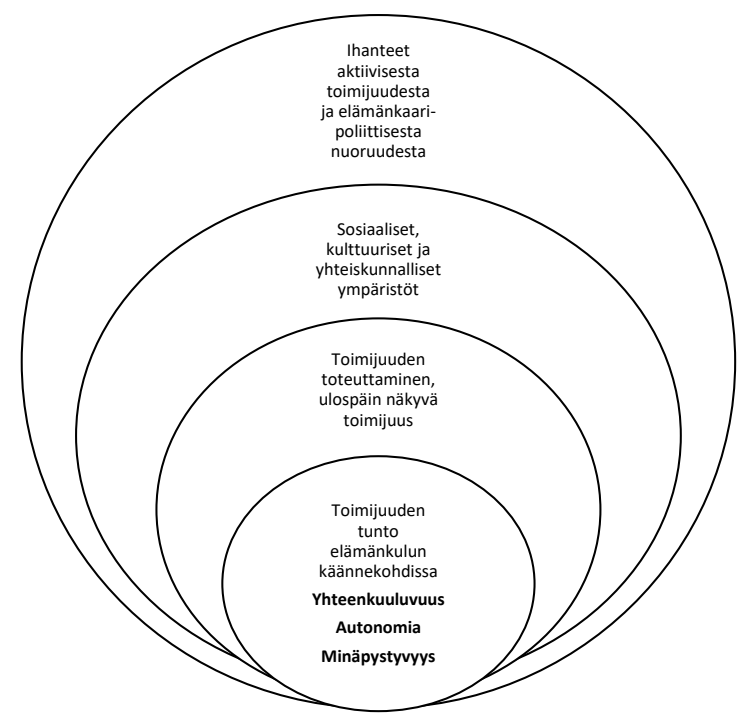

Kuvio 5. Toimijuuden tunto

luihin osallistumisen tarkasteleminen riitä avaamaan nuoren elämänkulkua. Käännekohtia tutkimalla voidaan tavoittaa nuoren elämän merkityksellisiä hetkiä, jotka eivät välttämättä liity siirtymiin, mutta jotka muuttavat nuoren elämänkulun suuntaa ja suhtautumista elämään. Kuviossa 5 nuoren toimijuuden tunto on sijoitettu ympyrän keskelle. Jos keskustelu nuorten toimijuudesta rajoittuu vain toimijuuden toteuttamisen (Cummings \& Schermerhorn 2002) tarkastelemiseen, ei nuoren sisäinen kokemus itsestään toimijana välttämättä avaudu. Elämänkulun käännekohdat ja toimijuuden tunto linkittyvät toisiin ihmisiin sekä kulttuurisiin ja yhteiskunnallisiin olosuhteisiin, joissa nuoret elävät.Ympyrän (Kuvio 5) ulkokehällä ovat ihanteet ja normit eli sosiaaliset, kulttuuriset ja yhteiskunnalliset kategoriat, jotka ohjaa- vat ihmisen valintoja (Ojala ym. 2009; Ronkainen 2006). Nuoret pohtivat valintojaan suhteessa odotusarvoiseen tapaan elää. Ajatus elämänkaaripolitiikasta voi ruokkia mielikuvaa lineaarisesti etenevästä, "oikeanlaisesta" elämänkulusta. Kuten tässä tutkimuksessa käytetyt elämänkulkua kuvaavat spiraalit osoittavat, on jokaisen nuoren elämänkulku uniikki. Johdannossa nostin esille ajatuksen siitä, kuinka elämänkaaripolitiikan sijaan voitaisiin puhua elämänkulkupolitiikasta (Suurpää 2009). Ideaa voitaisiin viedä vieläkin pidemmälle: elämänkulkupolitiikan rinnalla voitaisiin tarkastella elämänkulun käännekohtien politiikkaa. Näin nuoret pääsisivät kertomaan niistä elämänkulun muutosvoimaisista tapahtumista, joihin peilaten he rakentavat nykyistä ja tulevaa elämänkulkuaan. 


\section{KIRJALlisuUs}

Aaltonen, Sanna \& Lappalainen, Sirpa (2013) Samalla viivalla? Koulutuspolulta poikenneiden nuorten resurssit ja toisen asteen koulutus. Teoksessa Kristiina Brunila \& Katariina Hakala \& Elina Lahdelma \& ,Antti Teittinen (toim.) Ammatillinen koulutus ja yhteiskunnalliset eronteot. Helsinki: Gaudeamus, 110-127.

Ansell, Nicola \& Lorraine, van Blerk \& Haidu, Flora \& Robson, Elsbeth (2011) Spaces, times, and critical moments. A relational time-space analysis of the impacts of AIDS on rural youth in Malawi and Lesotho. Environment and Planning A: Economy and Space 43(3), 524-544. https://doi.org/10.1068/a4363

Bandura, Albert (1997) Self-efficacy in changing societies. Cambridge: Cambridge University Press.

Burkitt, Ian (1999) Bodies of thought. Embodiment, identity and modernity. London: Sage.

Clausen, John (1995) Gender, contexts, and turning points in adults' lives. Teoksessa Phyllis Moen \& Glen Elder \& Kurt Luscher (toim.) Examining lives in context! Perspectives on the ecology of human development. Washington DC: American Psychological Association, 365-389. https://doi. org/10.1037/10176-010

Cummings, Mark \& Schermerhorn, Alice (2002) A developmental perspective on children as agents in the family. Teoksessa Leon Kuczynski (toim.) Handbook of dynamics in parent-child relations. California: SAGE Publications, 91-108. https:// doi.org/10.4135/9781452229645.n5

Ecclestone, Kathryn \& Biesta, Gert \& Hughes, Martin (2010) Transitions in the lifecourse. The role of identity, agency and structure. Teoksessa Kathryn Ecclestone \& Gert Biesta \& Martin Hughes (toim.) Transitions and learning through the life course. London: Routledge, 1-15.

Elder, Glen (1998) The life course as a developmental theory. Child Development 69 (1), 1-12.

Elder, Glen \& Giele, Janet (2009) The craft of life course research. New York: Guilford Press. https://doi. org/10.1111/j.1467-8624.1998. tb06128.x

Gordon, Tuula (2005) Toimijuuden käsitteen dilemmoja. Teoksessa Anneli Meurman-Solin \& Ilkka Pyysiäinen (toim.) Ihmistieteet tänään. Helsinki: Gaudeamus, 114-130.

Habermas, Tilmann (2010) Autobiographical reasoning. Arguing and narrating from a biographical perspective. Teoksessa Tilmann Habermas (toim.) The development of autobiographical reasoning in adolescence and beyond. New directions for child and adolescent development 131. San Francisco: Jossey-Bass, 1-17. https://doi.org/10.1002/cd.285

Hall, Stuart (2002) Identiteetti, (suom.) Mikko Lehtonen \& Juha Herkman.Tampere:Vastapaino.

Hamilton, Myra \& Adamson, Elizabeth (2013) Bounded agency in young carers' lifecourse-stage domains and transitions. Journal of Youth Studies 16(1), 101-117. https://doi.org/10.1080/13676261.201 2.710743

Hass, Michael \& Allen, Quaylan \& Amoah, Michelle (2014) Turning points and resilience of academically successful foster youth. Children and Youth Services Review 44, 387-392. https://doi. org/10.1016/j.childyouth.2014.07.008

Holland, Janet \& Thomson, Rachel (2009) Gaining perspective on choice and fate. Revisiting critical moments. European Societies 11 (3), 451-469. https://doi. org/10.1080/14616690902764799

Häkkinen, Antti \& Salasuo, Mikko (2016) Sukupolvet ja hyvä elämä.Teoksessa Sami Myllyniemi (toim.) Arjen jäljillä. Nuorisobarometri 2015. Helsinki: OKM, Nuora \& Nuorisotutkimusverkosto/ Nuorisotutkimusseura, 183-192.

Ikonen, Hanna-Mari (2018) "Sitä palkintoo ei ehkä koskaan tule". Toimijuuden tunnustus ja maaseudun naisyrittäjät. Sosiologia 55(2), 115-129.

Jokinen, Kimmo \& Pirskanen, Henna (2015) Verkostokartta ja aikajana lasten moninaisten perhesuhteiden tutkimisessa. Teoksessa Marleena Mustola \& Johanna Mykkänen \& Marja Leena Böök \& Antti-Ville Kärjä (toim.) Visuaaliset menetelmät lapsuuden- ja nuorisotutkimuksessa. Helsinki: Nuorisotutkimusver- 
kosto, 46-54.

Juntunen, Anna (2019) "Minä uskon hyvään elämään.” Nuoret ja elämänkulussa rakentuva toimijuus. Helsinki: Helsingin yliopiston teologinen tiedekunta.

Juvonen, Tarja (2015) Sosiaalisesti kontrolloitu, hauraasti autonominen. Nuorten toimijuuden rakentuminen etsivässä työssä. Helsinki: Nuorisotutkimusverkosto/Nuorisotutkimusseura.

Kallinen, Kati \& Pirskanen, Henna \& Rautio, Susanna (2015) Sensitiivinen tutkimuksessa. Menetelmät, kohderyhmät, haasteet ja mahdollisuudet. Jyväskylä: United Press Global.

Kiilakoski, Tomi (2012) Kasvatus teknologisessa maailmassa. Helsinki: Nuorisotutkimusverkosto/Nuorisotutkimusseura.

Lee, Raymond (1993) Doing research on sensitive topics. London: Sage.

McAdams, Dan (2011) Life narratives. Teoksessa Karen Fingerman \& Cynthia Berg \& Jacqui Smith \& Toni Antonucci (toim.) Handbook of life-span development. New York: Springer, 589-610.

Mishler, Elliot (1986) Research interviewing. Context and narrative. Cambridge, MA: Harvard University Press.

Nikander, Pirjo (1999) Elämänkaaresta elämänkulkuun. Iän muuttuva merkitysmaailma. Teoksessa Ilkka Kangas \& Pirjo Nikander (toim.) Naiset ja ikääntyminen. Helsinki: Gaudeamus, 27-43.

Ojala, Hanna \& Palmu, Tarja \& Saarinen, Jaana (2009) Paikalla pysyvää ja liikkeessä olevaa. Feministisiä avauksia toimijuuteen ja sukupuoleen. Teoksessa Hanna Ojala \& Tarja Palmu \& Jaana Saarinen (toim.) Sukupuoli ja toimijuus koulutuksessa. Tampere:Vastapaino, 13-38.

Ojala, Hanna (2010) Opiskelemassa tavallaan.Vanhat naiset ikäihmisten yliopistossa. Tampere: Tampereen yliopisto.

Oravala, Sanna \& Rönkä, Anna (1999) Käännekohdat elämänkulussa. Psykologia 34 (4), 274-280.

Paju, Elina (2013) Lasten arjen ainekset. Etnografinen tutkimus materiaalisuudesta, ruumiillisuudesta ja toimijuudesta päiväkodissa. Helsinki:Tutkijaliitto.

Perkins, Douglas \& Zimmerman, Marc (1995) Empowerment theory, research and application. American Journal of Community Psychology 23 (5), 569-579.
https://doi.org/10.1007/BF02506982

Piispa, Mikko (2013) "Vapaasti olen saanut valita eikä mihkään ole pakotettu". Katsaus suomalaisen huippu-urheilijan elämänkulkuun. Teoksessa Mikko Piispa \& Helena Huhta (toim.) Epätavallisia elämänkulkuja. Huippu-urheilijat ja -taiteilijat 2000-luvun Suomessa. Helsinki: Nuorisotutkimusverkosto/Nuorisotutkimusseura, 13-55.

Piispa, Mikko \& Salasuo, Mikko (2014) Taiteilijan elämänkulku. Tutkimus nuorista taiteilijoista 2000-luvun Suomessa. Helsinki: Nuorisotutkimusverkosto/ Nuorisotutkimusseura.

Porkka, Jouko (2016) Rippikoulu ja isostoiminta aikuisuuteen kasvattajina. Sisäja ulkosyntyinen uskonnollisuus sekä sosiaalinen pääoma. Teoksessa Joona Salminen (toim.) Miten Suomi uskoo? Helsinki: Suomalainen Teologinen Kirjallisuusseura, 90-125.

Porkka, Jouko (2017) Rippikoululaisten ja isosten uskonnollisuuden ja motivaation muutos sekä Matteus-efekti. Teoksessa Jarmo Kokkonen (toim.) Tehdään ihmeitä! Osallisuus, vapaaehtoisuus, jäsenyys ja hengellisyys isostoiminnassa. Helsinki: Diakonia-ammattikorkeakoulu, 153-188.

Ronkainen, Suvi (2006) Haavoittunut kansakunta ja väkivallan toimijuus. Teoksessa: Mirva Lohiniva-Kerkelä (toim):Väkivalta - seuraamukset ja haavoittuvuus. Helsinki:Talentum.

Ronkainen, Suvi (2008) Kenen ongelma väkivalta on? Suomalainen hyvinvointivaltio ja väkivallan toimijuus. Yhteiskuntapolitiikka 4, 388-401.

Rutter, Michael (1996) Transitions and turning points in developmental psychopathology. As applied to the age span between childhood and mid-adulthood. International Journal of Behavioral Development 19 (3), 603-626. https://doi. org/10.1080/016502596385712

Saarelainen, Suvi-Maria (2017) Meaningful life with(out) cancer. Coping narratives of emerging Finnish adults. Helsinki: Helsingin yliopiston teologinen tiedekunta.

Sakasti, Tilastot, Varhaiskasvatus-, nuorisoja rippikoulutyö. http://sakasti.evl.fi/sakasti.nsf/sp?open\&cid=Content3F24FC. 
Luettu 27.3.2018.

Settersten, Richard (2003) Invitation to the life course. Toward new understandings of later life. New York: Baywood Publishing Company.

Shildrick,Tracy \& MacDonald, Robert (2008) Understanding youth exclusion. Critical moments, social networks and social capital. Youth and Policy 99, 46-64.

Suurpää, Leena (toim.) (2009) Nuoria koskeva syrjäytymistieto. Avauksia tietämisen politiikkaan. Helsinki: Nuorisotutkimusverkosto/ Nuorisotutkimusseura.

Thomson, Rachel \& Bell, Robert \& Holland, Janet \& Henderson, Seila \& McGrellis, Sheena \& Sharpe, Sue (2002) Critical moments. Choice, chance and opportunity in young people's narratives of transition. Sociology 36 (2), 335-354. https://doi. org/10.1177/0038038502036002006

Tolonen, Tarja (2005) Sosiaalinen tausta, sukupuoli ja paikallisuus nuorten koulusiirtymissä. Teoksessa Sinikka Aapola \& Kaisa Lehtokivi (toim.) Polkuja ja poikkeamia Aikuisuutta etsimässä. Helsinki: Nuorisotutkimusverkosto/Nuorisotutkimusseura, 35-65.
Vaattovaara, Virpi (2015) Elämänkulku ja toimijuus. Lapin maaseudun nuorista aikuisiksi 1990-2011. Rovaniemi: Lapin yliopiston kasvatustieteellinen tiedekunta.

Vehviläinen, Jukka (2006) Nuorten osallisuushankkeen hyvät käytännöt. Helsinki: Opetushallitus.

Wiles, Rose \& Prosser, Jon \& Bagnoli,Anna \& Clark, Andrew \& Davies, Katherine \& Holland, Sally \& Renold, Emma (2008) Visual ethics. Ethical issues in visual research. Review paper. Southampton: ESRC National Centre for Research Methods.

Wyn, Johanna \& Woodman, Dan (2006) Generation, youth and social change in Australia. Journal of Youth Studies 5, 495-514. https://doi. org/10.1080/13676260600805713 